\title{
KEABSAHAN SERTIFIKAT DARI PERBEDAAN JANGKA WAKTU PUBLISITAS DALAM PENDAFTARAN TANAH
}

\author{
Asriyanti Nuralifah \\ Universitas Surabaya \\ Email: asriyanti797@gmail.com
}

\begin{abstract}
Abstrak
Demi terwujudnya kesejahteraan masyarakat, pemerintah Indonesia saat ini dalam mengatur kepemilikan tanah dan memimpin penggunaannya telah menyelenggarakan pendaftaran tanah di seluruh wilayah Negara Republik Indonesia. Pendaftaran tanah ini merupakan kewajiban pemerintah yang bertujuan untuk menjamin kepastian hukum. Akan tetapi dalam pelaksanaannya terdapat perbedaan pengaturan jangka waktu pengumuman pembuktian pemilikan tanah data yuridis dan data fisik bidang tanah serta peta bidang-bidang tanah diumumkan antara Peraturan Menteri Agraria dan Tata Ruang/Badan Pertanahan Nasional Nomor 6 Tahun 2018 tentang Pendaftaran Tanah Sistematis Lengkap (PTSL) dengan Peraturan Pemerintah Nomor 24 Tahun 1997 tentang Pendaftaran Tanah. Oleh karena itu, dilakukakan penelitian ini untuk memperoleh kejelasan bagaimana keabsahan sertifikat yang diterbitkan dan bagaimana akibat hukum dari perbedaan peraturan dalam pendaftaran tanah terkait asas publisitas negatif berunsur positif.. Metode yang digunakan dalam penelitian ini adalah normatif dengan pendekatan perundang-undangan dan pendekatan analitis. Dari hasil penelitian ini kedudukan sertifikat berdasarkan perbedaan peraturan jangka waktu publisitas sah apabila tidak diadakan yudicial review dan tidak dibatalkan oleh pembatalan sertifikat.
\end{abstract}

Kata Kunci: Pengaturan asas publisitas, Perbedaan pengaturan, dan Keabsahan sertifikat

\section{Abstract}

In order to realize the welfare of society, this time Indonesian government in regulating land ownership and leading its use that have registered land in the entire territory of the Republic of Indonesia. This land registration is a government obligation that aims to guarantee legal certainty. However, in the implementation there are different arrangements 
for the period of announcement of proof of land ownership of juridical data and physical data on parcels of land and maps of land parcels announced between Minister of Agrarian and Spatial Planning / National Land Agency Regulation Number 6 in 2018 concerning Complete Systematic Land Registration (PTSL) with Government Regulation Number 24 of 1997 concerning Land Registration. Therefore, this research was carried out to obtain clarity on the validity of the certificates issued and how the legal consequences of the different regulations in land registration related to the principle of negative publicity are positive elements. The method used in this study is normative with a legal approach and analytical approach. From the results of this study the position of the certificate is based on differences in the rules of the period of validity of publicity if a judicial review is not held and is not canceled by the cancellation of the certificate.

Keywords: Setting publicity principles, Setting differences, Certificate validity

\section{PENDAHULUAN}

Tanah merupakan salah satu bentuk karunia Tuhan yang Maha Esa pada bangsa Indonesia sekaligus sumber daya alam yang strategis bagi bangsa, negara, dan rakyat. Tanah dapat dijadikan sebagai sarana untuk mencapai kesejahteraan hidup bangsa Indonesia sehingga diperlukan adanya campur tangan negara untuk turut mengaturnya. Hal tersebut sebagaimana tercantum dalam Pasal 33 ayat 3 Undang-Undang Dasar 1945 yang menyeebutkan bahwa "Bumi, Air dan Kekayaan Alam yang terkandung didalamnya dikuasai oleh negara dan dipergunakan untuk sebesar-besar kemakmuran rakyat". ${ }^{1}$ Secara alamiah kehidupan manusia tidak akan terpisahkan dengan tanah karena tanah merupakan pijakan untuk melangsungkan kehidupannya. Oleh sebab itu, tanah sangat penting dan dapat dikatakan sebagai kebutuhan primer bagi manusia. Hal tersebut dapat menimbulkan setiap orang akan selalu berusaha memiliki dan menguasainya sehingga menimbulkan banyak sengketa tanah di dalam masyarakat.

Timbulnya sengketa tanah dapat berupa tuntutan hak atas tanah, baik terhadap status tanah, prioritas, maupun kepemilikan tanah. Dalam menanggulangi permasalahan tersebut Pemerintah menyelenggarakan pendaftaran tanah yang diatur dalam Pasal 19 ayat (1) dan (2) UndangUndang Republik Indonesia Nomor 5 Tahun 1960 tentang Peraturan Dasar

${ }^{1}$ Lihat Pasal 33 Ayat (3) Undang-undang Dasar Negara Republik Indonesia Tahun 
Pokok-Pokok Agraria. Selain itu, pendaftaran tanah juga diatur dalam Peraturan Pemerintah Nomor 10 Tahun 1961 tentang Pendaftaran Tanah. Namun, dalam peraturan tersebut dinilai kurang efektif sehingga perlu dilakukan penyempurnaan. Dalam menyempurnakan peraturan yang lama, pemerintah membuat suatu aturan baru pada tanggal 8 juli 1997 berupa Peraturan Pemerintah Nomor 24 Tahun 1997 tentang Pendaftaran Tanah. Pelaksanaan pendaftaran tanah dilakukan oleh Badan Pertanahan Nasional (BPN) yang mana sekarang dinamakan sebagai Kementrian Agraria dan Penataan Ruang yaitu suatu institusi yang berwenang menerbitkan suratsurat hak atas tanah dan bertanggung jawab atas surat-surat yang diterbitkannya. ${ }^{2}$ Adapun pendaftaran tanah terbagi dalam dua macam yaitu dilakukan apabila objek tanah tersebut belum pernah didaftarkan sebelumnya (secara sistematik dan sporadik) dan pemeliharaan data pendaftaran tanah. ${ }^{3}$

Tujuan dari adanya pendaftaran tanah tersebut untuk memberikan jaminan atau kepastian hukum (Rechts Cadaster/Legal Cadaster) yang meliputi status hak yang terdaftar, kepastian subjek hak, dan kepastian objek hak. Adapun hasil dari jaminan tersebut berupa sertifikat tanah sebagai tanda bukti haknya. ${ }^{4}$ Dalam Pasal 32 ayat (1) Peraturan Pemerintah Nomor 24 Tahun 1997 tentang Pendaftaran Tanah disebutkan bahwa sertifikat yaitu surat atau lembaran kertas yang digunakan sebagai tanda bukti hak yang berlaku sebagai alat pembuktian yang kuat mengenai data fisik dan data yuridis sesuai dengan data yang ada dalam surat ukur dan buku tanah hak yang bersangkutan.

Soedikno Mertokusumo membagi pendaftaran tanah menjadi 2 macam asas yaitu : asas specialiteit dan asas openbaarheid. ${ }^{5}$ Asas specialiteit dalam menyelenggarakan pendaftaran tanah yaitu dilaksanakan atas dasar peraturan undang-undang yang berlaku saat ini yang mana secara teknis merupakan bagian dari masalah pengukuran, pemetaan, dan pendaftaran tanah dan peralihannya. Sedangkan asas openbaarheid (asas publisitas) merupakan asas yang memberikan data yuridis mengenai orang yang menjadi subyek hak, obyek hak atas tanah, serta proses pelaksanaan

${ }^{2}$ H. Ali Achmad Chomzah, Hukum Pertanahan Seri Hukum Pertanahan I dan II, Jakarta: Prestasi Pustaka, 2002, hlm. 125

${ }^{3}$ Abd. Rahim Lubis, Hukum Pendaftaran Tanah, Bandung: Mandar Maju, 2008, hlm. 15

${ }^{4}$ Urip Santoso, Pendaftaran dan Peralihan Hak Atas Tanah, Jakarta : Kharisma Putra Utama, 2010, hlm. 2

5 Boedi Harsono, Hukum Agraria Indonesia Sejarah Pembentukan Undangundang Pokok Agraria, Isi, dan Pelaksanaannya, Djambatan : Jakarta, 2003, hlm. 175 
peralihan dan pembebanannya. Adapun data tersebut memiliki sifat terbuka untuk umum yang berarti semua orang dapat melihatnya. ${ }^{6}$

Kepastian objek dan subjek hak sangat dibutuhkan dalam perjalanan hukum mengenai hak-hak atas tanah sehingga pemerintah di berbagai negara menyelenggarakan sistem keterbukaan atau pengumuman mengenai hak atas tanah (sistem publisitas). Menurut Peraturan Pemerintah Nomor 24 Tahun 1997 tentang Pendaftaran Tanah sistem publisitas yang digunakan di Indonesia ialah sistem hukum negatif yang memiliki unsur positif yang menghasilkan surat-surat tanda bukti hak yang mana berlaku sebagai alat pembuktian yang kuat seperti sertifikat.

Pelaksanaan pembuatan sertifikat tanah yang selama ini berjalan lambat menjadi pokok perhatian pemerintah agar cepat menanggulangi permasalahan tersebut. Oleh sebab itu, pemerintah melalui Kementerian Agraria Tata Ruang/Badan Pertanahan Nasional mempercepat pendaftaran tanah dengan berbagai program/proyek dengan segala keterbatasannya. Adapun program yang telah ada sebelumnya yaitu Proyek Administrasi Pertanahan (PAP), Land Management and Policy Development Project (LMPDP) atau proyek ajudikasi, Larasati, dan Program Nasional Agraria (PRONA), dari semua program tersebut dinilai belum mencapai target percepatan pendaftaran tanah yang efektif.

Melihat dari kurang efektifnya program-program yang sebelumnya maka dari itu pemerintah meluncurkan program baru yaitu Program Prioritas Nasional berupa Percepatan Pendaftaran Tanah Sistematis Lengkap (PTSL), Melalui program ini pemerintah memberikan jaminan kepastian hukum dan hak atas tanah yang di miliki masyarakat. ${ }^{7}$ Program tersebut dituangkan dalam Peraturan Menteri Agraria dan Tata Ruang/Kepala Badan Pertanahan Nasional Nomor 6 Tahun 2018 tentang Pendaftaran Tanah Sistematis Lengkap intruksi Presiden Nomor 2 Tahun 2018 tentang Pendaftaran Tanah Sistematis Lengkap di seluruh wilayah Republik Indonesia.

Salah satu persoalan penting terkait dengan pendaftaran tanah tersebut adalah asas publisitas yang mempunyai perbedaan pengaturan antara Peraturan Pemerintah dengan Peraturan Menteri. Asas publisitas dalam Pasal 24 Peraturan Kementerian Agraria Tata Ruang/Badan

\footnotetext{
${ }^{6}$ Ibid, hlm. 190

${ }^{7} \mathrm{Http}: / /$ www.atrbpn.go.id/beranda/apresiasi/-pelaksanaan-program-ptsl-padaacara-indonesia-award-2018-7751diakses pada tanggal 21 Maret 2019 pada pukul 06.06
} 
Pertanahan Nasional Nomor 6 Tahun 2018 tentang Pendaftaran Tanah Sistematis Lengkap, pembuktian pemilikan tanah dilaksanakan

pengumuman atau pemberitahuan mengenai data fisik dan data yuridis dalam jangka waktu 14 hari kerja. Ketentuan tersebut berbeda dengan Pasal 26 Peraturan Pemerintah Nomor 24 Tahun 1997 tentang Pendaftaran Tanah yaitu :

"Alat bukti yang dituangkan dalam daftar isian serta peta bidang maupun bidang-bidang tanah tersebut yang mana merupakan hasil dari pengukuran, wajib diumumkan dalam kurun waktu 30 (tiga puluh) hari (sistematik) atau 60 (enam puluh) hari (sporadic) dengan tujuan untuk memberikan kesempatan kepada pihak ketiga atau pihak yang berkepentingan agar dapat mengajukan keberatan".

Sedangkan dalam Pasal 24 Peraturan Menteri Agraria dan Tata Ruang/Kepala Badan Pertanahan Nasional Nomor 6 Tahun 2018 tentang Pendaftaran Tanah Sistematis Lengkap dijelaskan "Bahwa untuk memenuhi asas publisitas dalam pembuktian kepemilikan tanah, maka dilakukan pengumuman data fisik dan data yuridis yang dilaksanakan di kantor pertanahan dan kantor kepala desa/kelurahan daerah sekitar dalam kurun waktu 14 (empat belas) hari kerja". ${ }^{9}$ Perbedaan pengaturan antara Peraturan Pemerintah Nomor 24 Tahun 1997 tentang Pendaftaran Tanah dan Peraturan Menteri Agraria dan Tata Ruang/Kepala Badan Pertanahan Nasional Nomor 6 Tahun 2018 tentang Pendaftaran Tanah Sistematis Lengkap memberikan ruang potensi merugikan hak subyek hukum yang lain, karena pada asasnya dalam hierarki perundang-undangan peraturan yang lebih rendah tidak boleh bertentangan dengan peraturan yang lebih tinggi.

Berdasarkan latar belakang diatas, dapat dirumuskan permasalahan bagaimana keabsahan serifikat yang diterbitkan sebagai akibat dari perbedaan peraturan jangka waktu publisitas dalam pendaftaran tanah terkait asas publisitas negatif berunsur positif? Adapun tujuan penelitian disusun berdasarkan rumusan masalah yaitu untuk memperoleh kejelasan bagaimana keabsahan sertifikat yang diterbitkan dan bagaimana akibat hukum dari perbedaan peraturan dalam pendaftaran tanah terkait asas publisitas negatif berunsur positif.

\section{METODE PENELITIAN}

${ }^{8}$ Lihat Pasal Pasal 26 Peraturan Pemerintah Nomor 24 Tahun 1997 tentang Pendaftaran Tanah

9 Lihat Pasal 24 Peraturan Menteri Agraria dan Tata Ruang/Kepala Badan Pertanahan Nasional Nomor 6 Tahun 2018 tentang Pendaftaran Tanah Sistematis Lengkap 
Jenis penelitian yang digunakan adalah jenis penelitian YuridisNormatif.Untuk mengkaji pokok permasalahan, penelitian ini mempergunakan metode penelitian hukum normative,untuk itu yang menjadi focus dan sentral penelitian ini adalah berbagai aturan hukum dan literature atau bahan yang berkaitan dengan hukum.Pendekatan yang digunakan dalam hal penelitian bahan pustaka pada penelitian ini adalah pendekatan perundang-undangan (statute approach), pendekatan ini dilakukan untuk menelaah dan memahami semua undang-undang dan regulasi yang terkait dengan isu hukum yang sedang penulis teliti.Penelitian ini juga mengunakan pendekatan konseptual (konseptual approach).Pendekatan yang bersifat yuridis-normatif tersebut akan dilakukan dengan mempergunakan bahan hukum primer, bahan hukum sekunder dan bahan hukum tersier. ${ }^{10}$ Teknik pengumpulan bahan hukum yang digunakanadalah studi pustakan dengan analisis menggunakan metode penelitian deskriptif-kualitatif.

\section{PEMBAHASAN}

\section{Perbedaan Pengaturan Jangka Waktu Publisitas dalam Pendaftaran Tanah}

Pendaftaran tanah merupakan hal yang sangat penting bagi manusia karena terkait hak kepemilikan atas tanah yang dimilikinya. Dalam pendaftaran tanah terdapat beberapa prosedur yang harus dipenuhi sehingga surat keterangan hak milik atau sertifikat dapat diterbitkan. Salah satu prosedur pendaftaran tanah yaitu asas publisitas atau pemberitahuan kepada khalayak umum mengenai tanah yang dimilikinya dengan jangka waktu yang telah ditentukan. Adapun pembahasan mengenai jangka waktu publisitas pendaftaran tanah akan di bahas pada sub bab selanjutnya.

\section{Jangka Waktu Publisitas Pendaftaran Tanah Berdasarkan Peraturan Pemerintah Nomor 24 Tahun 1997 tentang Pendafataran Tanah}

Berdasarkan ketentuan Peraturan Pemerintah Nomor 24 tahun 1997 tentang Pendaftaran Tanah Pasal 1 ayat (1) menyatakan pendaftaran tanah adalah rangkaian kegiatan yang dilakukan oleh pemerintah secara terus menerus, berkesinambungan, dan teratur yang mana meliputi pengumpulan, pengolahan, pembukuan dan penyajian serta pemeliharaan data fisik dan data yuridis dalam bentuk peta dan daftar mengenai bidang-bidang tanah dan satuan-satuan rumah susun termasuk pemberian surat tanda bukti

\footnotetext{
${ }^{10}$ Ibid, hal. 29.
} 
haknya bagi bidang-bidang tanah yang sudah ada haknya dan hak milik atas satuan rumah susun serta hak-hak tertentu yang membebaninya. ${ }^{11}$

Dari pengertian tersebut kata "rangkaian" menunjukkan adanya berbagai kegiatan dalam penyelenggaraan pendaftaran tanah yang berkaitan satu dengan yang lain yang mana berurutan menjadi satu kesatuan rangkaian yang bermuara pada tersedianya data yang diperlukan dalam memberikan jaminan kepastian hukum dibidang pertanahan bagi masyarakat, Sedangkan kata "terus menerus, berkesinambungan" menunjukkan pada pelaksanaan kegiatan yang sekali dimulai dan tidak akan ada akhirnya sampai persoalan itu selesai. Data yang telah terkumpul dan tersedia harus disesuaikan dengan perubahan-perubahan yang terjadi kemudian sehingga tetapsesuai dengan keadaan terakhir. Pendaftaran tanah akan menghasilkan kepastian bukti hak atas tanah yang merupakan alat bukti yang kuat sebagai dasar status kepemilikan tanah. Dengan adanya bukti hak atas tanah, maka seseorang dapat mempertahankan haknya dan mempergunakan hak tersebut sesuai dengan kepentingannya.

Pada saat dilakukan pendaftaran tanah maka hubungan pribadi antara seseorang dengan tanah diumumkan kepada pihak ketiga atau masyarakat umum sebagai prinsip yang mendasar dalam hukum kebendaan asas keterbukaan. Oleh sebab itu, siapapun yang melakukan peralihan dan pendaftaran hak atas tanah harus diumumkan sehingga sejak diumumkannya pendaftaran tanah tersebut maka setiap orang dianggap telah mengetahuinya. Pengumuman atau asas publisitas pendaftaran tanah merupakan pengumuman kepada masyarakat mengenai status kepemilikan yang di atur dalam Peraturan Pemerintah Nomor 24 Tahun 1997 tentang Pendaftaran Tanah dalam Pasal 26 ayat (1) yang berbunyi "Daftar isian beserta peta bidang atau bidang-bidang tanah yang bersangkutan sebagai hasil pengukuran diumumkan selama 30 hari (tiga puluh) hari dalam pendaftaran tanah secara sistematik atau 60 (enam puluh) hari dalam pendaftaran tanah secara sporadik untuk memberikan kesempatan kepada pihak yang berkepentingan mengajukan keberatan". ${ }^{12}$

Adapun daftar isian yang dimaksud dalam pasal tersebut yaitu mengenai pengumpulan dan pengelolaan data fisik dan data yuridis. Data fisik yang dimaksud ialah mengenai letak, batas luas bidang tanah dan satuan rumah susun yang terdaftar. Sedangkan data yuridis yaitu mengenai status hukum bidang tanah dan satuan rumah susun yang didaftar dari tahapan-tahapan pendaftaran tanah. Pelaksanaan pendaftaran tanah dalam

\footnotetext{
${ }^{11}$ Lihat Pasal 1 ayat 1 Peraturan Pemerintah Nomor 24 Tahun 1997

${ }^{12}$ Lihat Pasal 26 ayat 1 Peraturan Pemerintah tentang Pendaftaran Tanah
} 
Peraturan Pemerintah Nomor 24 Tahun 1997 tentang Pendaftaran Tanah meliputi kegiatan pendafatran tanah untuk pertama kali dan pemeliharaan data pendafatran tanah.

Kegiatan pendaftaran untuk pertama kali dilakukan melalui konversi atau pengakuan hak atau pemberian hak agar semua orang mengetahui atau dianggap mengetahui siapa pemilik suatu hak bidang tanah tersebut, apa status hak dari tanah tersebut, dan apabila sudah terdaftar maka dilakukan pengumuman. Kegiatan pendaftaran tanah untuk pertama kali dilakukan melalui kegiatan pendaftaran tanah secara sistematik dan kegiatan pendafataran tanah secara sporadik. ${ }^{13}$

Kegiatan pendaftaran tanah secara sistematik adalah kegiatan pendaftaran tanah yang dilakukan secara serentak meliputi semua obyek pendafatran tanah yang belum didaftar dalam wilayah atau bagian wilayah suatu desa/kelurahan. Sedangkan pendaftaran tanah secara sporadik adalah kegiatan pendaftaran tanah untuk pertama kali mengenai satu atau beberapa obyek pendafatran tanah dalam wilayah atau bagian wilayah suatu desa/kelurahan secara individual atau massal. Kegiatan pendaftaran tanah yang dilakukan oleh pemerintah untuk pelaksanaan pendafataran tanah untuk pertama kali berkaitan dengan pengumuman atau asas publisitas (openbaarheid) ialah pengumuman kepada masyarakat mengenai status kepemilikan.

Adapun yang diumumkan dalam pendafataran tanah yaitu mengenai letaknya, batas-batasnya, luasnya (data fisik) dan mengenai haknya, siapa pemegang haknya, dan ada atau tidak hak-hak pihak lain yang membebaninya (data yuridis). Pengumuman dari hasil penelitian data yuridis dan hasil pengukuran yang digunakan yakni daftar isian dan peta tanah yang telah ditetapkan tersebut yang dilakukan secara sistematik diumumkan selama 30 hari yang ditempatkan di kantor panitia ajudikasi, kantor kepala desa bersangkutan dan tempat lain ( Kantor Rukun Warga atau lokasi tanah yang bersangkutan) yang dianggap perlu yang mana pengumuman tersebut meliputi peta bidang tanah dengan data luas masingmasing bidang tanah (data fisik bidang tanah) dan data kepemilikan tanah (data yuridis bidang tanah) yang dituangkan dalam daftar isian. Sedangkan dalam pendaftaran tanah secara sporadik yang dilaksanakan atas permintaan pihak yang berkepentingan (yang bersifat individual) daftar Isian dan peta

${ }^{13}$ Lihat Pasal 13 Ayat 1 Peraturan Pemerintah tentang Pendaftaran Tanah 
tanah yang telah ditetapkan tersebut diumumkan selama 60 hari yang ditempatkan di kantor pertanahan, kantor kepala desa bersangkutan dan tempat lain (Kantor Rukun Warga, atau lokasi tanah yang bersangkutan) yang dianggap perlu bahkan dapat juga dilakukan di media massa.

Dalam jangka waktu publisitas secara sistematis maupun sporadik tersebut digunakan untuk mengajukan keberatan mengenai data fisik dan data yuridis yang dimumkan dalam rangka pembuatan berita acara pengesahan pengumuman data fisik dan data yuridis, dalam berita acara pengesahan tersebut menjadi dasar untuk pembukuan hak atas tanah yang bersangkutan dalam buku tanah, pengakuan hak atas tanah, serta pemberian hak atas tanah.

\section{Jangka Waktu Publisitas Pendaftaran Tanah Berdasarkan Peraturan Menteri Agraria dan Tata Ruang/Kepala Badan Pertanahan Nasional Nomor 6 Tahun 2018 tentang Pendafaaran Tanah Sisitematis Lengkap}

Berdasarkan Pasal 1 ayat (2) Peraturan Menteri Agraria dan Tata Ruang/Kepala Badan Pertanahan Nasional Nomor 6 Tahun 2018 tentang Pendaftaran Tanah Sistematis Lengkap menjelaskan bahwa Percepatan Pendaftaran Tanah Sistematis Lengkap (PTSL) adalah kegiatan pendaftaran tanah untuk pertama kali yang dilakukan secara serentak bagi semua objek pendaftaran tanah di seluruh wilayah Republik Indonesia dalam satu wilayah desa/kelurahan atau nama lainnya yang setingkat dengan itu yang mana meliputi pengumpulan data fisik dan data yuridis mengenai satu atau beberapa objek pendaftaran tanah untuk keperluan pendaftarannya.

Dalam pelaksaan kegiatan dalam rangka percepatan proses pendaftaran tanah untuk pertama kali meliputi pengumpulan dan penetapan data fisik dan data yuridis mengenai satu atau beberapa obyek pendaftaran tanah. Dalam hal kegiatan pendaftarannya yang dilakukan dengan tahapan: ${ }^{14}$

a. Penetapan lokasi kegiatan percepatan Pendaftaraan Tanah Sistematis Lengkap (PTSL)

Adapun penetapan lokasi dapat dilakukan dalam satu wilayah desa/kelurahan secara bertahap maupun dalam satu hamparan. dan apabila dilakukan dari beberapa desa atau kelurahan diupayakan agar desa/kelurahan tersebut yang menjadi pendaftaran tanah sistematis lengkap letaknya berdekatan.

14 Lihat Pasal 3 ayat (3) - Pasal 36 Peraturan Menteri Agraria dan Tata Ruang/Badan Pertanahan Nasional Nomor 6 Tahun 2018 
b. Pembentukan dan penetapan panitia ajudikasi Pendaftaran Tanah Sistemtis Lengkap (PTSL) dan Satuan Tugas (SATGAS)

Panitia Adjudikasi dalam pendaftaran tanah sitstematis lengkap adalah organisasi yang dibantu oleh kantor petanahan dengan tujuan pelaksanaan pendaftaran tanah sistematis lengkap, sedangkan Satuan Tugas (SATGAS) adalah unit organisai yang membantu pelaksanaan panitia adjudikasi. Sebelum melaksanakan tugasnya panitia adjudikasi dan Satuan Tugas (SATGAS) wajib bersumpah dihadapan pejabat yang mengangkatnya.

c. Penyuluhan

Penyuluhan dilakukan oleh kepala kantor pertanahan beserta panitia djudikasi Pendaftaran Tanah Sistematis Lengkap (PTSL), satuan tugas fisik dan satuan tugas yuridis terhadap masyarakat baik yang sudah maupun belum memiliki sertifikat.

d. Pengumpulan dan pengelolaan data fisik dan data yuridis bidang tanah

Pengumpulan, pengolahan dan pemeliharaan data fisik dan data yuridis penetapan hak dan pendaftaran tanah menggunakan daftar isian, dalam pengumpulan data fisik yakni dilakukan melalui kegitan pengukuran dan pemetaan bidang tanah, pengumpulan data yuridis meliputi pengumpulan alat bukti mengenai kepemilikan atau penguasaan tanah, baik bukti tertulis, keterangan saksi dan/ pernyataan yang bersangkutan. Standar, kriteria, metode, prosedur, dan mekanisme pengumpulan, peengolahan dan penyajian serta pemeliharaan data dan dokumen yuridis dan fisik sesuai dengan ketentuan peraturan perundang-undangan.

e. Pemeriksaan tanah

Pemeriksaan dilakukan untuk memastikan keterangan yang tertuang didalam data yuridis sesuai dengan keadaan dilapangan. Dilakukan dengan cara menggali informasi yang meliputi kesesuaian nama peserta Pendaftaran Tanah Sistematis Lengkap (PTSL) serta membandingkan keterangan yang tertera di dalam formulir isian inventarisasi dan dokumen/data yuridis dengan kesesuaian dengan kondisi penguasaan, penggunaan tanah tersebut di lapangan, serta kesesuaian letak, batas dan luas yang tertuang dalam data fisik (Peta Bidang Tanah) dengan kenyataan di lapangan.

f. Pengumuman data fisik dan data yuridis

Hasil pemeriksaan tanah yang menyimpulkan dapat dibukukan dan atau diterbitkannya Sertifikat hak atas tanah atas satu bidang tanah 
diumumkan dalam papan pengumuman di Kantor Pertanahan dan/atau Kantor Kelurahan/Desa dan/atau Sekretariat RT/RW lokasi bidang tanah tersebut selama 14 hari kerja, dengan tujuan untuk diketahui khalayak masyarakat dan memberi kesempatan kepada pihak-pihak yang berkepentingan untuk menyampaikan keberatan jika ada keberatan.

g. Penerbitan keputusan pemberian hak atas tanah

Penerbitan keputusan hak atas tanah berdasarkan berita acara hasil pengumuman, panitia ajudikasi pendaftaran tanah bidang yuridis menyiapkan naskah surat keputusan Penetapan hak atau keputusan penegasan/pengakuan hak serta menandatangani penetapan hak atau keputusan penegasan/pengakuan hak.

h. Pembukuan hak atas tanah

Dalam pembukuan hak atas tanah panitia ajudikasi percepatan bidang yuridis menyiapkan/mencetak buku tanah dan menandatangani buku tanah yang dilakukan sesuai dengan ketentuan peraturan perundang-undangan.

i. Penerbitan sertifikat hak atas tanah

Panitia ajudikasi percepatan menyerahkan sertifikat hak atas tanah kepada pemegang hak atau kuasanya dengan mencatatnya dalam daftar isian penyerahan sertifikat.

j. Penyerahan sertifikat hak atas tanah

Penyerahan hasil pelaksanaan kegiatan pendaftaran tanah sistematis lengkap (PTSL) dibuat dalam bentuk berita acara serah terima berkas dan warkah hasil kegiatan Pendaftaran Tanah Sistematis Lengkap (PTSL) yang ditandatangani oleh panitia adjudikasi kepala kantor pertanahan.

Salah satu tahapan dari kegiatan pelaksanaan pendaftaran tanah sistematis lengkap tersebut adalah kegiatan publikasi atau pengumuman berupa penyajian data yang dihimpun secara terbuka bagi umum di kantor pertanahan berupa daftar-daftar dan peta sebagai informasi bagi umum yang akan melakukan perbuatan hukum mengenai tanah yang terdaftar yang diatur dalam Pasal 24 Peraturan Menteri Agraria dan Tata Ruang/Kepala Badan Pertanahan Nasional Nomor 6 Tahun 2018 tentang Pendaftaran Tanah Sistematis Lengkap (PTSL) : "Untuk memenuhi asas publisitas dalam pembuktian pemilikan tanah, data yuridis dan data fisik bidang tanah dan peta bidang-bidang tanah diumumkan dengan menggunukan formulir pengumuman data fisik dan data yuridis bidang tanah dan peta bidangbidang tanah diumumkan dengan menggunakan formulir pengumuman data fisik dan data yuridis selama 14 (empat belas) hari kalender dikantor panitia 
adjudikasi Pendaftaran Tanah Sistematis Lengkap dan Kantor Kepala Desa/Kelurahan". ${ }^{15}$

Dari pasal diatas pendaftaran tanah menggunakan pendaftaran tanah untuk pertama kali yang mana hasil pemeriksaan tanah yang dapat dibukukan dan atau diterbitkannya sertifikat hak atas tanah atas satu bidang tanah diumumkan dalam papan pengumuman di kantor pertanahan /kantor kelurahan, desa, sekretariat rt/rw lokasi bidang tanah tersebut selama 14 hari kerja mengenai data yuridis yang berisi keterangan status hukum bidang tanah dan satuan rumah susun yang didaftar, pemegang haknya dan hak pihak lain serta beban lain yang membebaninya, data fisik yang menyebutkan mengenai keterangan letak, batas, luas bidang tanah dan satuan rumah susun yang didaftar pemegang haknya dan hak pihak lain serta beban lain yang membebaninya serta peta bidang tanah yang merupakan hasil pengukuran secara kadasteral yang dapat dipakai untuk rekonstruksi batas di lapangan dan batas-batasnya merupakan batas yang sah menurut hukum. Dengan tujuan untuk diketahui khalayak masyarakat dan memberi kesempatan kepada pihak-pihak yang berkepentingan untuk menyampaikan keberatan jika ada keberatan.

\section{Pengaturan Jangka Waktu Publisitas Berdasarkan Asas Per-Undang- Undangan}

Peraturan Menteri Agraria Tata Ruang/Kepala Badan Pertanahan Nasional Nomor 6 Tahun 2018 tentang Pendaftaran Tanah Sistematis Lengkap (PTSL) adalah jangka waktu pengumuman yang lebih cepat daripada ketentuan Peraturan Pemerintah Nomor 24 Tahun 1997 tentang Pendaftaran Tanah. Peraturan Pemerintah tersebut menyebutkan bahwa hasil dalam pengukuran diumumkan selama 30 (tiga puluh) hari dalam pendaftaran tanah secara sistematik, sedangkan pada Peraturan Menteri Agraria Tata Ruang/Kepala Badan Pertanahan Nasional Nomor 6 Tahun 2018 tentang Pendaftaran Tanah Sistematis Lengkap (PTSL) pengumuman pembuktian pemilikan tanah, data yuridis dan data fisik bidang tanah serta peta bidang-bidang tanah diumumkan selama 14 (empat belas) hari.

Hans Kelsen menyebutkan bahwa hukum merupakan sistem norma yang dinamis yakni selalu dibentuk dan dihapus oleh lembaga-lembaga otoritas-otoritasnya yang berwenang membentuknya berdasarkan norma yang lebih tinggi, sehingga norma yang lebih rendah (inferior) dapat dibentuk berdasarkan norma yang lebih tinggi (superior), pada akhirnya

${ }^{15}$ Lihat Pasal 24 Angka 2 Peraturan Menteri Agraria Dan Tata Ruang Kepala Badan Pertanahan Nasional 
hukum menjadi berjenjang-jenjang dan berlapis-lapis membentuk suatu hierarki. ${ }^{16}$ Perbedaan pengaturan antara Peraturan Menteri Nomor 6 Tahun 2018 tentang Pendaftaran Tanah Ssitematis Lengkap (PTSL) dengan Peraturan Pemerintah Nomor 24 Tahun 1997 tentang Pendaftaran Tanah yaitu mengenai waktu pengumuman data fisik dan data yuridis. Ketentuan tersebut apabila ditinjau dari asas-asas peraturan perundang-undangan yaitu $: 17$

\section{Asas lex superior derogate legi inferior}

Yaitu peraturan lebih tingggi mengesampingkan yang rendah, dalam hal ini peraturan yang lebih rendah tidak dapat

mengubah atau mengesampingkan ketentuan peraturan yang lebih tinggi derajatnya.

2. Asas lex specialis derogate legi generi

Yaitu asas hukum yang bersifat khusus mengesampingkan hukum yang bersifat umum. Ketentuan lex specialis harus sederajat dengan ketentuan lex generalis. Misalnya Undang-Undang dengan UndangUndang, Peraturan Pemerintah dengan Peraturan Pemerintah, dan seterusnya.

3. Asas lex posterior derogate legi prioro

Yaitu pada peraturan yang sederajat, peraturan yang paling baru menggantikan peraturan yang lama.

Apabila ditinjau dari asas-asas peraturan perundang-undangan tersebut yaitu menganut pada asas lex superior derogate legi inferior yang mana menjelaskan bahwa peraturan yang lebih tinggi mengesampingkan peraturan yang lebih rendah yang mana dalam hal ini Peraturan Pemerintah lebih tinggi derajatnya daripada Peraturan Menteri. Sedangkan apabila ditinjau peraturan hierarki perundang-undangan yaitu pada Undang-Undang Nomor 12 tahun 2011 tentang Pembentukan Peraturan Perundang-undangan yang telah dijelaskan bahwa bentuk aturan hukum ditentukan sebagai berikut : ${ }^{18}$

a. Undang-Undang Dasar Negara Republik Indonesia 1945

b. Ketetapan Majelis Permusyawaratan Rakyat

c. Undang-Undang/Peraturan Pemerintah Pengganti Undang-undang

d. Peraturan Pemerintah

e. Peraturan Presiden

\footnotetext{
${ }^{16}$ Maria Farida Indrati S, Ilmu Perundang-undangan 1, Yogyakarta: Kanisius, 2007, hlm. 69

${ }_{17}$ Bagir Manan, Hukum Positif Indonesia, Yogyakarta: 2004, hlm. 56

18 Pasal 7 ayat (1) Undang-UndangNomor 12 tahun 2011 tentang Pembentukan Peraturan Perundang-undangan
} 
f. Peraturan Menteri

g. Peraturan Daerah Kabupaten/Kota

Akibat posisi norma hukum mempunyai struktur hierarki tersebut maka keberlakuan suatu norma hukum yang lebih rendah akan sangat tergantung kepada norma yang ada di atasnya dan menjadi landasan atau dasar bagi berlakunya norma tersebut. Ketentuan-ketentuan yang digariskan oleh suatu norma yang lebih tinggi merupakan das sollen bagi pembentukan norma yang lebih rendah. Dengan demikian, suatu norma hukum yang lebih rendah dengan sendirinya akan tercabut atau tidak berlaku lagi apabila norma hukum yang ada diatasnya yang menjadi dasar dan menjadi sumber berlakunya norma tersebut dicabut atau dihapus dengan kata lain norma hukum yang berkedudukan lebih rendah tidak boleh bertentangan dengan norma hukum yang lebih tinggi tingkatannya yang menjadi dasar atau sumber berlakunya norma itu.

\section{Keabsahan Sertifikat Dari Perbedaan Jangka Waktu Publisitas dalam Pendaftaran Tanah}

Pendaftaran tanah itu diwajibkan kepada para pemegang hak untuk memberikan kepastian hukum. Adapun kepastian hukum yang dimaksud adalah meliputi :

1. Kepastian mengenai orang/badan hukum yang menjadi pemegang hak atas tanah terebut (kepastian berkenaan dengan subyek hak atas tanah).

2. Kepastian mengenai letak tanah, batas-batas tanah, panjang dan lebar tanah. (kepastian mengenai obyek hak atas tanah).

Dengan demikian apabila telah dilakukan pemeriksaan tanah sebagai bagian dari proses pendaftaran tanah maka akan jelas bahwa pemegang hak (subyek) maupun tanahnya (obyek) telah terdaftar dan pemegang hak tersebut benar-benar berhak atau mempunyai hubungan hukum dengan tanahnya. Bukti bahwa pemegang hak berhak atas tanahnya adalah dengan pemberian tanda bukti hak yang berlaku sebagai alat pembuktian yang kuat yang dinamakan sertifikat tanah. ${ }^{19}$ Dengan kata lain hak-hak atas tanah dibukukan dalam buku tanah dan diterbitkan sertifikat sebagai tanda bukti pemilikan tanahnya, dengan demikian penyelenggaraan pendaftaran tanah atau pendaftaran hak atas tanah yang dilaksanakan berdasarkan ketentuan Undang-Undang Pokok Agraria (UUPA) dan Peraturan Pemerintah Nomor

${ }^{19}$ Lihat Pasal 4 ayat (1) Peraturan Pemerintah Nomor 24 Tahun 1997 tentang Pendaftaran Tanah 
24 Tahun 1997 tentang Pendaftaran Tanah telah menggunakan asas publisitas dan asas spesialitas.

Asas publisitas tercermin denganadanya pendaftaran tanah yang menyebutkan subyek haknya, jenis haknya, peralihandan pembebanannya Sedangkan asas spesialitas tercermin dengan adanya data-data fisik tentang hak atas tanah tersebut seperti luas tanah, letak tanah, dan batas-batas tanah. Asas publisitas dan asas spesialitas ini dimuat dalam suatu daftar guna dapat diketahui secara mudah oleh siapa saja yang ingin mengetahuinya, sehingga siapa saja yang ingin mengetahui data-data atas tanah itu tidak perlu lagi mengadakan penyelidikan langsung ke lokasi tanah yang bersangkutan karena segala data-datatersebut dengan mudah dapat diperoleh di kantor pertanahan.

Dalam Pasal 26 Peraturan Pemerintah Nomor 24 Tahun 1997 tentang Pendaftaran Tanah pengumuman (publisitas) data fisik dan data yuridis yang akan dijadikan dasar pendaftaran bidang tanah yang bersangkutan diberikan jangka waktu selama 30 (tiga puluh) hari sedangkan dalam Pasal 24 Peraturan Menteri Agraria dan Tata Ruang/Kepala Badan Pertanahan Nasional Nomor 6 Tahun 2018 tentang Pendaftaran Tanah Sistematik Lengkap (PTSL) meneyebutkan bahwa janga waktu pengumuman pendaftaran tanah dipangkas menjadi 14 (empat belas) hari saja tanpa sebelumnya mengubah ketentuan Pasal 26 Peraturan Pemerintah Nomor 24 Tahun 1997 tentang Pendaftaran Tanah.

Terdapat beberapa alasan yang mendasari tidak berlakunya suatu aturan seperti pencabutan, pengahapusan dan perubahan. ${ }^{20}$ Suatu aturan akan tetap ada dan berlaku sampai adanya pencabutan. Pencabutan, pengahapusan, dan perubahan dapat dilakukan oleh badan atau lembaga yang berwenang karena beberapa alasan, salah satunya sudah tidak relevan dengan perkembangan zaman. Pencabutan, pengahapusan, dan perubahan dapat juga dilakukan melalui peraturan perundang-undangan yang lebih tinggi atau sederajat. Dalam hal suatu aturan mengalami pencabutan dan penghapusan, maka aturan tersebut dapat dikatakan sudah tidak memilki kekuatan hukum dan secara sah telah tidak berlaku sebagai aturan, lain halnya dengan perubahan, suatu aturan yang mengalami perubahan masih dapat berlaku sampai dinyatakan tidak berlaku oleh peraturan yang lebih tinggi atau sejenis namun yang lebih baru atau spesifik. Sehingga perubahan suatu aturan masih dimungkinkan terhadap pemberlakuannya.

${ }^{20}$ Soeprapto, Ilmu Perundang-undangan dan dasar-dasar pembentukannya, Yogyakarta: Kanisius, 1998 
Berdasrkan teori Hans Kelsen menyebutkan bahwa norma-norma hukum itu berjenjang dan berlapis-lapis dalam suatu hierarki dimana suatu norma yang lebih rendah berlaku, bersumber dan berdasar pada norma yang lebih tinggi lagi, demikian seterusnya sampai pada suatu norma yang disebut norma dasar (gurnnorm). Ketidaksingkronan itu membatalkan aturan hukum yang lebih rendah, namun dalam praktik penyelenggaraan bernegara ketidaksingkronan aturan itu tidak otomatis membatalkan aturan yang lebih rendah sebelem aturan yang lebih rendah dibatalkan oleh pengadilan yang berwenang dalam melakukan judicial Review. Pada Pasal 8 ayat (2) Undang-Undang Nomor 12 Tahun 2011 tentang Pembentukan Peraturan Perundang-undangan menegaskan "Peraturan perundangundangan sebagaimana dimaksud pada ayat (1) diakui keberadaannya dan mempunyai kekuatan hukum mengikat sepanjang diperintahkan oleh peraturan perundang-undangan yang lebih tinggi atau dibentuk berdasarkan kewenangan."

Dari perbedaan jangka waktu publisitas pendaftaran tanah antara Peraturan Pemerintah Nomor 24 Tahun 1997 tentang Pendaftaran Tanah dengan Peraturan Menteri Agraria dan Tata Ruang/Kepala Badan Pertanahan Nasional tentang Pendaftaran Tanah Sisitematis Lengkap yang mana mengacu pada asas lex superior derogate legi inferior ialah, bahwa Peraturan Pemerintah lebih memiliki kekuatan hukum apabila dibandingkan dengan Peraturan Menteri, sebab kedudukan Peraturan Pemerintah dalam hierarki peraturan perundang-undangan dapat dikatakan lebih tinggi. Namun pemberlakuan suatu aturan tidak hanya melihat dari tinggi rendahnya aturan tersebut dalam hierarki peraturan perundang-undangan, namun juga terhadap proses pemberlakuan aturan itu sendiri. Dalam hal perbedaan jangka waktu publisitas pendaftaran tanah antara Peraturan Pemerintah dan Peraturan Menteri tidak memiliki kekurangan atau cacat hukum yang dapat mengakibatkan suatu aturan tersebut tidak berlaku atau dinyatakan batal demi hukum. Sehingga meskipun ada perbedaan terhadap jangka waktu publisitas pendaftaran tanah, namun sertifikat yang diterbitkan sama-sama memiliki kekuatan hukum dan dapat dikatakan sah.

Sedangkan ketika jangka waktu publisitas dalam Peraturan Menteri yang lebih cepat dari Peraturan Pemerintah tersebut masih tetap dilaksanakan tanpa memperhatikan kepentingan pihak lain maka bisa mengakibatkan hilangnya hak subyek hukum yang lain, adapun hak yang dimaksud adalah ketika jangka waktu pengumuman data fisik dan data yuridis yang di atur dalam Peraturan Pemerintah Nomor 24 Tahun 1997 tentang Pendaftaran Tanah diberikan waktu 30 (tiga puluh) hari sedangkan 
dalam Peraturan Menteri Nomor 6 Tahun 2018 tentang Pendaftaran Tanah Sistematis Lengkap menyebutkan selama 14 (empat belas) hari yang mana berarti ada waktu 16 (enam belas) hari yang hilang, dari hilangnya waktu (enam belas) 16 hari tersebut ada hak subyek hukum yang hilang ketika masih menguasai dan ingin membuktikan kepemilikan obyek hak tanah tersebut.

Dalam Pasal 27 ayat 3 Peraturan Pemerintah Nomor 24 Tahun 1997 tentang Pendaftaran Tanah dan Pasal 24 ayat 7 Peraturan Menteri Agraria dan Tata Ruang/Kepala Badan Pertanahan Nasional Nomor 6 Tahun 2018 tentang Pendaftaran Tanah Sistematik Lengkap (PTSL) disebutkan bahwa apabila kurang lengkapnya data yang tersedia atau masih adanya keberatan yang tidak dapat diselesaikan maka ketua panitia adjudikasi mengusahakan agar secepatnya keberatan yang diajukan diselesaikan secara musyawarah untuk mufakat, apabila tidak membawa hasil mufakat maka akan diajukan ke pengadilan.

Setelah jangka waktu pengumuman berakhir, data fisik dan data yuridis disahkan oleh panitia adjudikasi yang dibuat dalam bentuk berita acara pengesahan pengumuman data fisik dan data yuridis.Pasal 24 ayat 6 Peraturan Menteri Agraria dan Tata Ruang/Kepala Badan Pertanahan Nasional menyebutkan apabila pada waktu pengesahan data fisik dan data yuridis masih terdapat kekuranglengkapan data atau masih terdapat keberatan yang belum diselesaikan, maka data fisik dan data yuridis tetap disahkan dengan hanya diberikan catatan pada berita acara pengesahan data fisik dan data yuridis mengenai hal-hal yang belum lengkap/keberatan yang belum diselesaikan, dalam arti lain bukan alasan menunda dilakukannya pembuatan berita acara hasil pengumuman data fisik dan data yuridis. Hal tersebut jelas bahwa terdapat hak subyek hukum yang dilanggar ketika masih ada orang yang menguasai tanah dan ingin membuktikan kepemilikan objek tanah tersebut.

Selain itu, berdasarkan asas publisitas negatif berunsur positif dalam Pasal 32 ayat (1) Peraturan Pemerintah tentang Pendaftaran Tanah, yang mana negara bukan hanya melindungi pemegang hak atas tanah yang sebenarnya dari tindakan orang lain yang mengalihkan haknya tanpa diketahui oleh pemegang hak sebenarnya melainkan juga menjamin dengan sempurna bahwa nama yang terdaftar dalam buku tanah adalah tidak dapat dibantah. Yang mana disini sertifikat dapat dikatakan sah secara hukum apabila dalam proses dan hasilnya tidak dilakukan dengan melanggar hukum. 


\section{KESIMPULAN}

Terdapat perbedaan jangka waktu (publisitas) pengumuman mengenai data fisik dan data yuridis dalam Pasal 26 Peraturan Peraturan Pemerintah Nomor 24 Tahun 1997 tentang Pendaftaran Tanah dengan Pasal 24 Peraturan Menteri tentang Agraria dan Tata Ruang/Kepala Badan Pertanahan Nasional Nomor 6 Tahun 2018 tentang Pendaftaran Tanah Sistematis Lengkap (PTSL) bertentangan dengan asas peraturan perundangudangan lex superior derogate legi inferior dan asas hierarki pembentukan peraturan perundang-undangan Nomor 12 Tahun 2011. Akibat hukum dari perbedaan peraturan jangka waktu publisitas pendaftaran tanah dalam Peraturan Pemerintah Nomor 24 Tahun 1997 tentang Pendaftaran Tanah dengan Peraturan Menteri Agraria dan Tata Ruang/Kepala Badan Badan Pertanahan Nasional Republik Indonesia Nomor 6 Tahun 2018 tentang pendaftaran tanah Sistematis Lengkap ialah kedudukan sertifikat yang diterbitkan dari kedua peraturan tersebut sah sebelum ada putusan Judicial Review, sedangkan dampak dari jangka waktu publisitas perbedaan pengaturan yang lebih pendek tersebut ialah mengenai hilangnya hak subyek hukum lain.

\section{DAFTAR PUSTAKA}

\section{Buku}

Ali, H. Achmad Chomzah, Hukum Pertanahan Seri Hukum Pertanahan I dan II. Jakarta. Prestasi Pustaka. 20024

Alamsyah, Saragih. Pengecualian Informasi di Badan Publik Negara. Jakarta. Sekretariat Komisi Informasi Pusat. 2012

Ali, H. Zaenuddin. Metode Penelitian Hukum. Jakarta. Sinar Grafika. 2016

Erna, Tri Rusmala. Dasar-Dasar Ilmu Hukum. Yogyakarta. Widya Mataram. 2005

Fajar, Mukti Yulianto Achmad. Penelitian Hukum Normatif dan Empiris. Yogyakarta. Pustaka Pelajar. 2010

Fajar, Mukti dan Yulianto Achmad. Penelitian Hukum Normatif dan Empiris. Yogyakarta. PustakaPelajar. 2010

Farida, Maria Indrati S. Ilmu Perundang-undangan 1. Yogyakarta. Kanisius. 2007

Hermanses, S. Pendaftaran Tanah di Indonesia. Jakarta. Direktorat Jenderal Agraria. 1981 
Harsono, Boedi. Hukum Agraria Indonesia Sejarah Pembentukan Undangundang Pokok Agraria, Isi, dan Pelaksanaanya. Djambatan. Jakarta. 2003

Huda, Ni'matul. Negara Hukum Demokrasi dan Judicial Review. Yogyakarta. UII Press. 2005

Ibrahim, Jhonny. Teori Dan Metodelogi Penelitian Hukum Normatif. Malang. Bayumedia Publishing. 2007

Kelsen, Hans. Teori Umum Tentang Hukum Negara (Theory Of Law and State). Bandung. Nusa Media. 2010

Konijnenbelt, Van Wijk. Hoofdtukken Van Administrtief Recht. Culembor. 1988

Lubis, Abd. Rahim. Hukum Pendaftaran Tanah. Bandung. Mandar Maju. 2008

\section{Peraturan Perundang-undangan:}

Undang-Undang Dasar 1945 Undang-Undang Nomor 12 Tahun 2011 tentang pembentukan Peraturan Perundang-undangan UndangUndang Nomor 5 Tahun 1960 tentang Peraturan Dasar Pokok Agraria (Lembaran Negara Republik Indonesia Tahun 1960 Nomor 104, Tambahan Lembaran Negara Republik Indonesia Nomor 2034)

Peraturan Pemerintah Nomor 24 Tahun 1997 tentang Pendaftaran Tanah Peraturan Menteri Negara Agraria/Kepala Badan Pertanahan Nasional Nomor 3 Tahun 1997 tentang Ketentuan Pelaksanaan Peraturan Pemerintah Nomor 24 Tahun 1997 tentang Pendaftaran Tanah Peraturan Menteri Agraria dan Tata Ruang/Kepala Badan Pertanahan Tanah Nomor 6 Tahun 2018 tentang Pendaftaran Tanah Sistematis Lengkap

\section{Internet}

Http://www.atrbpn.go.id/beranda/apresiasi/-pelaksanaan-program-ptsl-padaacara-indonesia-award-2018-7751 diakses pada tanggal 21 Maret 2019 pada pukul 06 